\title{
Understanding Long-Term Solute Transport in Sedimentary Basins: Simulating Brine Migration in the Alberta Basin
}

\author{
Final Report, Grant No. DE-FG02-04ER15515 \\ Principle Investigator: Alicia M. Wilson, awilson@sc.edu, (803) 777-1240
}

\begin{abstract}
Mass transport in deep sedimentary basins places important controls on ore formation, petroleum migration, $\mathrm{CO}_{2}$ sequestration, and geochemical reactions that affect petroleum reservoir quality, but large-scale transport in this type of setting remains poorly understood. This lack of knowledge is highlighted in the resource-rich Alberta Basin, where geochemical and hydrogeologic studies have suggested residence times ranging from hundreds of millions of years to less than $5 \mathrm{My}$, respectively. Here we developed new hydrogeologic models that were constrained by geochemical observations to reconcile these two very different estimates. The models account for variable-density fluid flow, heat transport, solute transport, sediment deposition and erosion, sediment compressibility, and dissolution of salt deposits, including $\mathrm{Cl} / \mathrm{Br}$ systematics. Prior interpretations of $\mathrm{Cl} / \mathrm{Br}$ ratios in the Alberta Basin concluded that the brines were derived from evaporatively-concentrated brines that were subsequently diluted by seawater and freshwater; models presented here show that halite dissolution must have contributed strongly as well, which implies significantly greater rates of mass transport. This result confirms that $\mathrm{Cl} / \mathrm{Br}$ ratios are subject to significant non-uniqueness and thus do not provide good independent indicators of the origin of brines. Salinity and $\mathrm{Cl} / \mathrm{Br}$ ratios provided valuable new constraints for basin-scale models, however. Sensitivity studies revealed that permeabilities obtained from core- and field-scale tests were appropriate for basin-scale models, despite the differences in scale between the tests and the models.

Simulations of groundwater age show that the residence time of porefluids in much of the basin is less than $100 \mathrm{My}$. Groundwater age increases with depth and approaches $200 \mathrm{My}$ in the deepest part of the basin, but brines are significantly younger than their host rocks throughout the basin.
\end{abstract}

\section{Introduction}

Knowledge of the origin and evolution of brines in sedimentary basins is critical for understanding processes such as petroleum migration, formation of ore deposits, sedimentary diagenesis and the long-term consequences of carbon sequestration in saline aquifers. However, hydrogeological and geochemical tools for estimating the residence time of brines have yielded very different results.

Hydrogeologic models that have been used to investigate brine migration have suggested that steady-state topography-driven groundwater flow could flush brines out of huge foreland basins in less than 5 My (Deming and Nunn, 1991; Appold and Garven, 1999). Other hydrogeologic work indicates that brines could be preserved much longer if lower permeabilities are used (Adams et al., 2004) or if brines are isolated below anomalously-pressured beds (Wilson et al., 2003). It is, however, often difficult to constrain permeabilities in basin-scale models. 


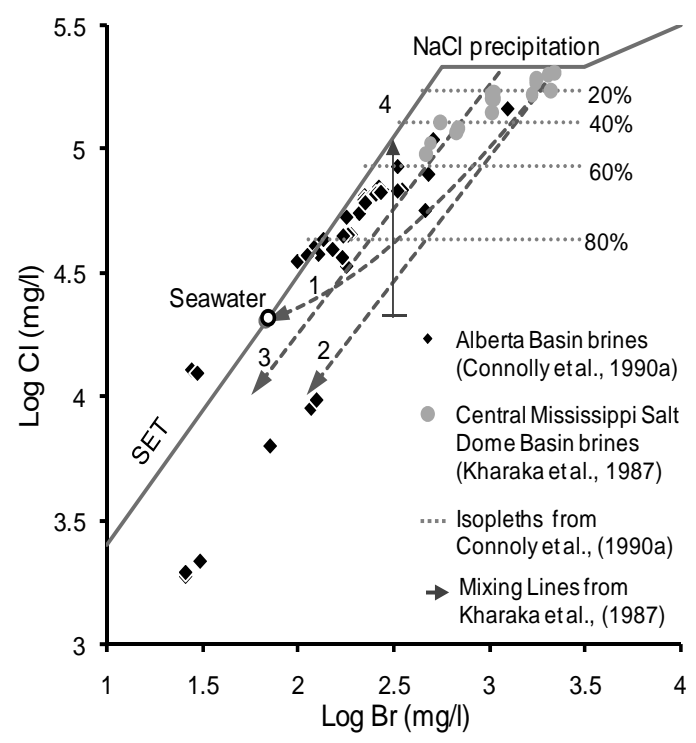

Figure 1. Log-log plot of $\mathrm{Cl}-\mathrm{Br}$ systematics with data from Connolly et al. (1990a) and Kharaka et al (1987). Solid line is seawater evaporation trajectory (SET). Isopleths (dotted lines) show percentage of mixing between meteoric waters and evaporatively-concentrated brines (after Connolly et al., 1990a). Numbered mixing lines (modified from Kharaka et al., (1987) represent: ' 1 ' mixing between seawater and evaporatively-concentrated brines; ' 2 ' mixing between meteoric water and evaporatively-concentrated brines; ' 3 ' mixture of meteoric water, evaporativelyconcentrated brines, and halite dissolution; '4' trend if mixture of meteoric water and evaporativelyconcentrated brines dissolves halite containing 70 ppm Br-. (From Gupta, 2009).

Geochemical studies have commonly relied on Cl-Br systematics (Carpenter, 1978) to distinguish between brines that formed by seawater evaporation and those that formed by evaporite dissolution in sedimentary basins. Brines that plot above the seawater evaporation trajectory are usually interpreted as being derived from halite dissolution, and those that plot below are said to have formed by evaporation beyond halite saturation, with subsequent dilution by freshwater or seawater. The latter origin implies very limited rates of solute transport in deep sedimentary basins, but uncertainty arises because significant halite dissolution may occur before diluted brines of evaporative origin rise back up to the SET, depending on the degree of evaporation beyond halite saturation and the degree of dilution of the original brine (Figure 1).

In this study, we combined these two approaches by using geochemical observations to constrain hydrogeologic models of the Alberta Basin, Canada, where numerous previous studies related to the origin and migration of brines have focused. This method allowed us to investigate the uncertainty associated with non-unique $\mathrm{Cl} / \mathrm{Br}$ ratios while also improving constraints on basin-scale hydrogeologic models. The models were then used to calculate the residence time of porefluids in the Alberta Basin.

\section{The Alberta Basin}

The Alberta Basin forms part of the Western Canada Sedimentary Basin and extends from $\sim 48^{\circ} \mathrm{N}$ to $\sim 61^{\circ} \mathrm{N}$ and from $\sim 109^{\circ} \mathrm{W}$ to the Rocky Mountains (Figure 2a). The basin is filled with a wedge of northeast striking sedimentary rocks where Cretaceous and Tertiary foreland basin sediments, associated with the Laramide Orogeny (100 to $60 \mathrm{Ma}$ ), were deposited unconformably over Paleozoic passive margin sediments that enclose Devonian evaporites, which are primarily halite (Figure 2b). Maximum uplift of the Rockies occurred around 60-55 Ma. Subsequent erosion (55 Ma to present) removed up to $1900 \mathrm{~m}$ of sediments from the western part of the cross-section 
(Nurkowski, 1984). Salinity increases with depth in a pattern that generally parallels the dip of the Prairie Evaporite (Figure 3).

Several origins have been proposed for brines contained in the Alberta Basin ( White, 1965; Clayton et al., 1966; Billings et al., 1969; Hitchon et al., 1969, 1971; Rittenhouse, 1967). More recent studies interpreted $\mathrm{Cl} / \mathrm{Br}$ ratios, concluding that brines in the Alberta Basin are derived solely from evaporation of seawater (Connolly et al., 1990a; Spencer, 1987). Halite dissolution was ruled out as a significant source of brine on the grounds that a large volume of seawater and even larger volume $(>85 \%)$ of meteoric water would be required to explain the $\mathrm{Cl} / \mathrm{Br}$ compositions (Connolly et al., 1990a). More recently, Michael et al. (2003) reported $\mathrm{Cl} / \mathrm{Br}$ compositions that plotted above the seawater evaporation trajectory in the deep western part of the basin, indicating likely halite dissolution. The $\mathrm{Cl} / \mathrm{Br}$ ratios from that study that plotted on the seawater evaporation trajectory, but were interpreted as derived from evaporation of seawater. Grasby and Chen (2005) analyzed $\mathrm{Cl} / \mathrm{Br}$ compositions of brine spring waters in the region. The $\mathrm{Cl} / \mathrm{Br}$ compositions of the springs plotted to the left of the seawater evaporation trajectory and were therefore interpreted as being derived from halite dissolution, but these samples were assumed to be unrelated to the deeper basinal brines.

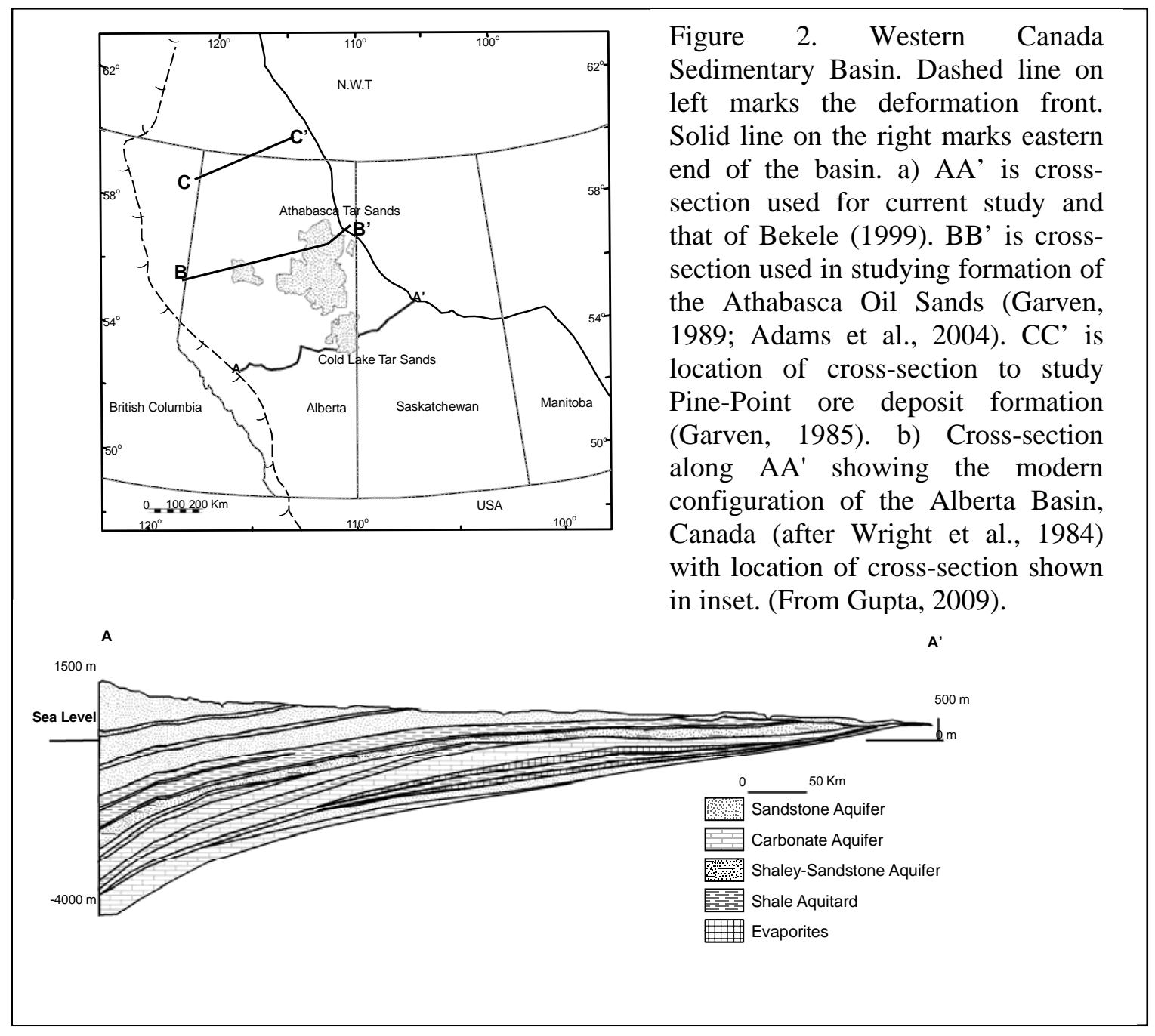


Hydrogeologic models of the Alberta basin include fluid flow and heat transport models that were used to explore the role of topography-driven flow in the formation of the Pine Point carbonate-hosted Pb-Zn deposit (Garven, 1985) and the Athabascan Oil Sands (Garven, 1989) in the northern portion of the basin (Figure 2a). Adams et al. (2004) showed that the permeability values used in Garven's models allowed brines to be flushed out in less than $2 \mathrm{My}$, but these models did not include evaporites as a source of salinity. Original brines were retained in simulations that used much lower permeabilities (Adams et al., 2004). Bekele (1999) and Bekele et al. (2000, 2002) simulated fluid flow, heat transport and petroleum migration farther south in the basin (Figure 2a) using permeability values based on published model data, drill-stem tests and core data for this region. They concluded that secondary oil migration in the Viking was a result of hydrodynamic forcing. Fluid flow rates on the order of $\mathrm{cm} / \mathrm{yr}$ to $\mathrm{m} / \mathrm{yr}$ were required in the Viking formation after uplift of the Rockies for oil to migrate into the easternmost Viking oil fields (Bekele et al., 2002), which places important lower limits on the regional permeability structure of the basin.

\section{Numerical models of brine migration and $\mathrm{Cl}-\mathrm{Br}$ systematics}

We used a 2D finite element FORTRAN program, COMPACT (Wilson et al., 1999), to simulate variable-density fluid flow, heat and solute transport and sediment compaction in the Alberta Basin. We modified COMPACT to allow erosional unloading, associated decompaction and halite precipitation/dissolution. Fluid viscosity and density were calculated as a function of salinity, temperature and viscosity (Batzle and Wang, 1992). Halite dissolution/precipitation was the only geochemical reaction simulated. In the simulations, halite was composed of $\mathrm{Na}+, \mathrm{Cl}-$, and $\mathrm{Br}$ - that was assumed to have partitioned into solid halite at the time of precipitation. The concentration of $\mathrm{Na}^{+}$is commonly affected by processes such as albitization, but this reaction is not extensive in the Alberta Basin (Connolly, et al. 1990a) and was thus not simulated.

A $700 \mathrm{Km}$, southwest-northeast cross-section (Figure 2b) was chosen to take advantage of critical information (geochemical, hydrogeologic, geothermal, tectonic) from previous studies (Connolly et al., 1990a; Bekele, 1999) for input into models. Porosity and permeability values for our baseline simulation were taken from Bekele (1999; 2002). Additional permeability models were evaluated in sensitivity studies, focusing particularly on the question of whether brines could be retained without halite dissolution if permeabilities were reduced.

\section{Boundary Conditions}

Along the upper boundary of the simulation domain, hydraulic head was specified based on the water table elevation in non-marine areas and hydrostatic pressure in marine areas. Specified solute boundary concentrations were also varied for marine and nonmarine conditions. Temperature for the upper boundary was set at $10{ }^{\circ} \mathrm{C}$. The top of the crystalline basement marked the lower boundary for fluid flow. A non-uniform heat flux, ranging from $40 \mathrm{~mW} / \mathrm{m}^{2}$ in the west to $60 \mathrm{~mW} / \mathrm{m}^{2}$ in the east (Bachu and Burwash, 1994, Majorowicz, et al., 1999), was applied along this boundary. A no-flow boundary condition was applied at the eastern and western boundaries.

Sedimentation, erosion, subsidence, and uplift rates were estimated by backstripping the basin using layer thicknesses from the geologic cross section of Wright 
et al. (1984) and ages from Mossop and Shetsen (1994). Erosion rates were computed based on thickness of eroded overburden (Nurkowski, 1984; Bustin, 1991). Deposition occurred from $100 \mathrm{Ma}$ to $60 \mathrm{Ma}$ in all of our simulations. Uplift and erosion rates can be difficult to determine, so we tested several possible scenarios.

\section{Initial Conditions}

Simulations began at the onset of foreland basin development circa $100 \mathrm{Ma}$. Initial conditions for hydraulic head and temperature were determined from a steady state simulation. We assumed that brines were formed by evaporation beyond halite saturation (Connolly et al., 1990a) and that the dense brines were all retained through the end of the passive margin stage, which provides the most favorable chance for original evaporatively-concentrated brines to be preserved. Accordingly, chloride concentration at the start of the simulation was set at halite saturation. The aqueous bromide concentration for brines was set to be 26 times that of seawater. Effects of uncertainties in the initial evaporative concentration of the brines, concentration of $\mathrm{Br}$ - in solid halite, and dispersivities were gauged using sensitivity studies. Two endmember cases were chosen for simulations of groundwater age: an initial age of $300 \mathrm{My}$ (the age of the oldest rocks in the basin when the simulation began) and an initial age of 0 My (assuming complete flushing of the basin). The initial age does not affect final calculations of the residence time of porefluids.

\section{Results}

Fluid flow results from the baseline simulation were consistent with those of Bekele (1999), showing compaction-driven flow during deposition of the foreland basin sediments followed by topography-driven flow after uplift began. Our results also indicate development of buoyancy-driven flow in the deeper parts of the basin due to thermo-haline convection. As described in more detail by Gupta et al. (submitted), the baseline simulation also produced salinities and $\mathrm{Cl} / \mathrm{Br}$ compositions that are consistent with the data of Connolly et al. (1990a). At the end of the simulation (modern conditions), the maximum salinity in the deepest part of the basin was $\sim 88 \mathrm{~g} / \mathrm{l}$ (Figure 3), a reduction of $\sim 55 \%$ from initial conditions, due to a combination of diffusional losses and topography-driven flushing. In the deep western part of the basin, final salinities were derived from mixing between original residual brines, seawater and freshwater over the last 100 million years (Figure 4). In other parts of the basin, original brines were strongly diluted, and high salinities reflect significant halite dissolution.

$\mathrm{Cl} / \mathrm{Br}$ ratios show marked variation across the basin, and their evolution changes sharply once freshwater begins to enter the basin (Figure 5). In the west (0 to $200 \mathrm{~km}$ ), brines are derived from evaporatively-concentrated brines that are first diluted by seawater and then by freshwater, after uplift. In the center of the basin (200 to $400 \mathrm{~km}$ ), brines are a mixture of evaporatively-concentrated brines, seawater, freshwater, and halite-derived brines. In the eastern portion of the basin (400 to $700 \mathrm{~km}$ ), brines are derived primarily from dissolution of halite diluted by seawater and freshwater.

We varied the permeability of the sediments to determine the uniqueness of this result. Permeabilities higher than those of the baseline simulation, including 

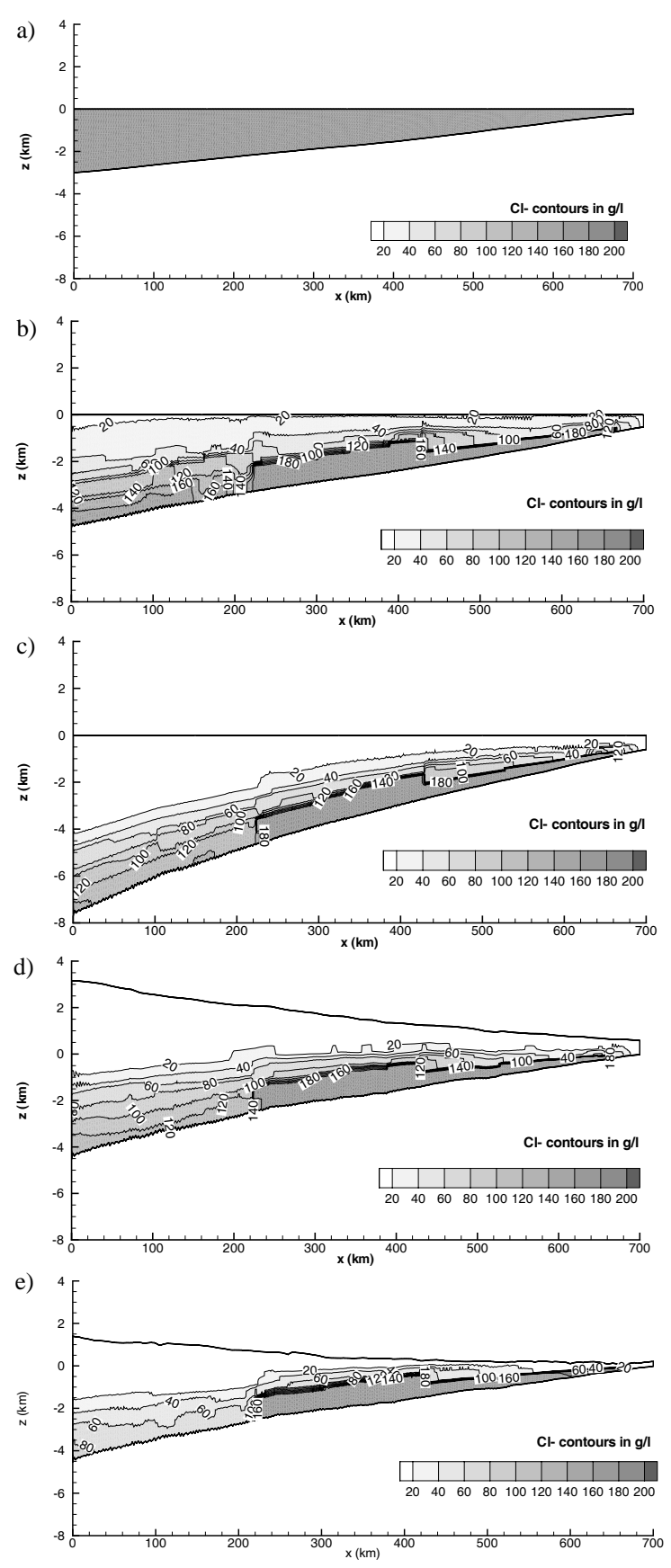

Figure 3. Simulated salinity evolution at (a) $100 \mathrm{Ma}$, (b) $77 \mathrm{Ma}$ (end of marine deposition), (c) $60 \mathrm{Ma}$ (end of foreland), (d) $55 \mathrm{Ma}$, and (e) modern conditions. (From Gupta, 2009). permeabilities based on Garven (1985), allowed excessive flushing of brines and dissolution of halite. Permeabilities from Adams et al. (2004) that allowed brines to be retained in the Athabasca simulation were approximately one order of magnitude smaller than those in our baseline simulation. Using these permeabilities, simulated salinities were too high in shallow portions of the basin and too low at greater depths, especially near the halite bearingevaporite beds. However, when aquifer permeabilities were reduced by three orders of magnitude compared to those of the baseline simulation, they also matched modern salinities. The reduction in permeability also restricted solute transport to the extent that halite dissolution did not occur, and the $\mathrm{Cl} / \mathrm{Br}$ compositions in that simulation were consistent with field data. However fluid flow rates were reduced to only $10^{-5}$ to $10^{-6} \mathrm{~m} / \mathrm{yr}$ in the Viking formation, too low for hydrodynamically-driven secondary oil migration up the Viking Formation (Bekele et al., 2002).

Additional sensitivity studies showed that varying the degree of the evaporative concentration of $\mathrm{Br}-(11 \mathrm{x}$ to $45 \mathrm{x}$ that of seawater, Connolly et al. 1990a) shifted the simulated $\mathrm{Cl} / \mathrm{Br}$ compositions horizontally in the $\mathrm{Cl}-\mathrm{Br}$ space, but they remained in the span of the data and still plotted primarily below the seawater evaporation trajectory (Figure 10). Changes in the initial degree of evaporative concentration did not affect the salinity because additional $\mathrm{Cl}$ - at high concentrations is sequestered in halite beds. Simulation results were insensitive to geologically feasible variations in the rate and timing of uplift and erosion in the Alberta Basin. 


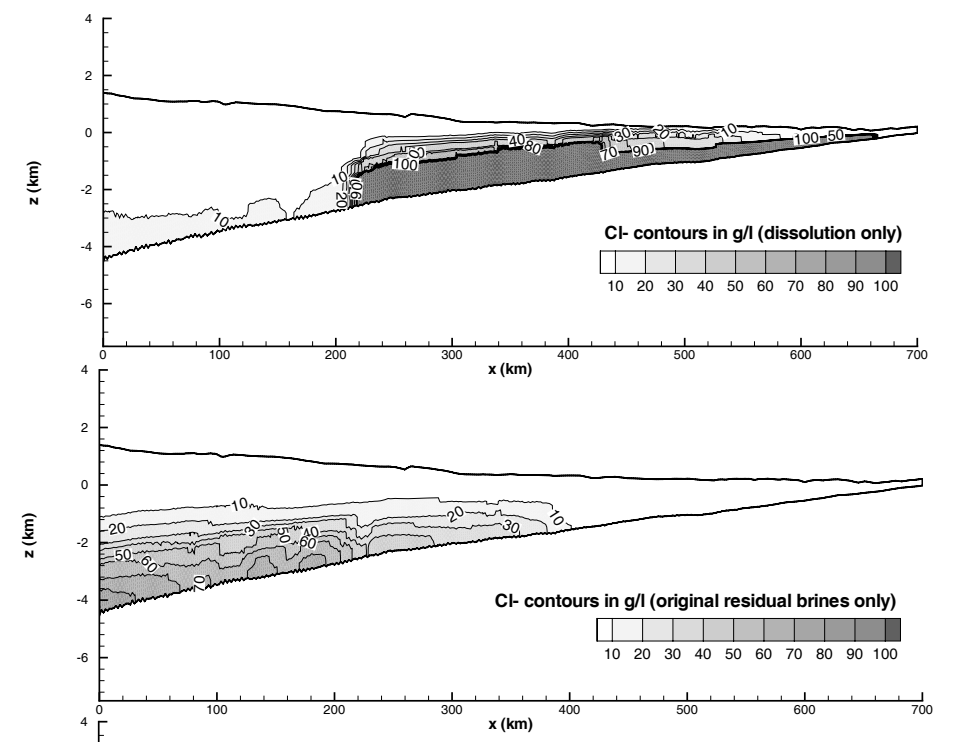

Figure 4. Origin of salinity in the baseline simulation. (a) Salinity derived from halite dissolution. (b) Salinity retained from evaporativelyconcentrated brines. Brines in the center of the basin, where Connolly et al. (1990a,b) worked, are of mixed origin. (From Gupta, 2009).
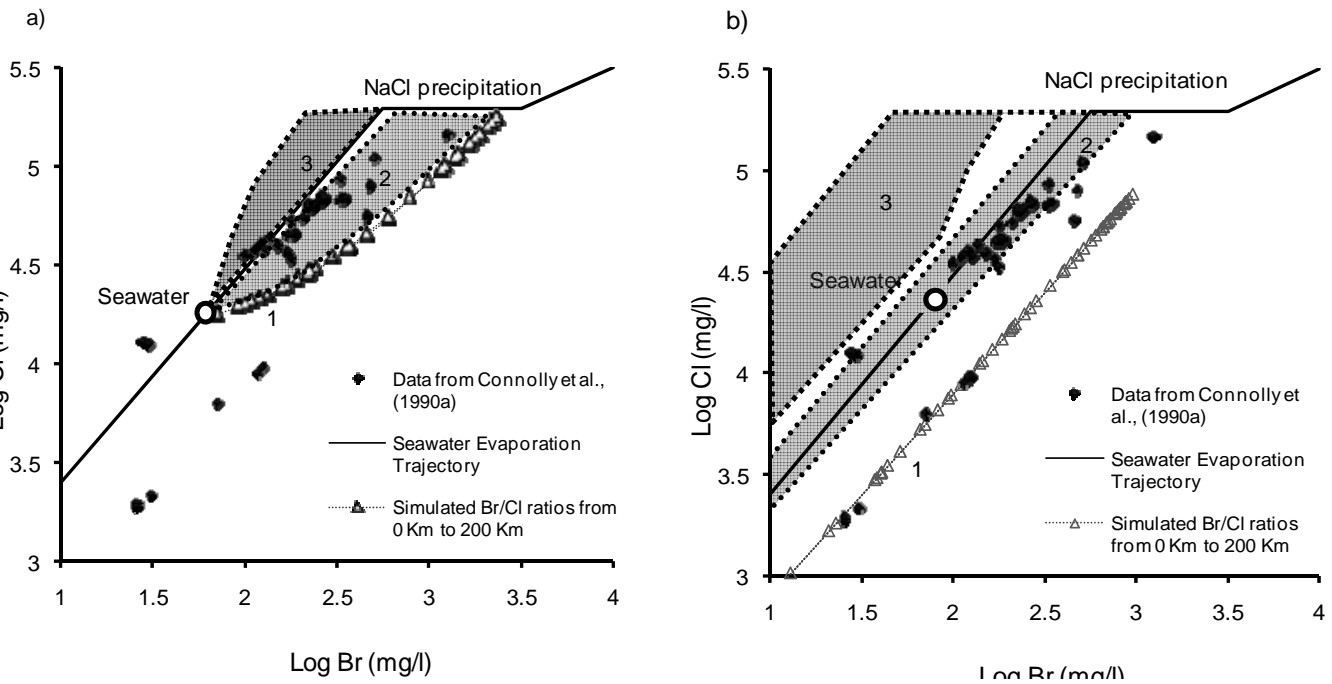

Figure 5: Simulated $\mathrm{Cl} / \mathrm{Br}$ ratios a) at the end of deposition of marine sediments, and b) in modern day Alberta Basin in comparison to data from Connolly et al. (1990a) at different lateral distances along cross-section. ' 1 ' (triangles) is the mixing line for waters between $0 \mathrm{Km}$ and $200 \mathrm{Km}$, which represent evaporatively-derived brines mixed with seawater and freshwater. Zone ' 2 ' (light shaded region) represents waters between $250 \mathrm{Km}$ and $350 \mathrm{Km}$. These waters are derived from evaporativelyconcentrated brines, halite dissolution-derived brines, seawater and freshwater mixing. Zone ' 3 ' (darker shaded region) represents waters between 400 and $700 \mathrm{Km}$, which derive their $\mathrm{Cl} / \mathrm{Br}$ ratios predominantly from halite dissolution and mixed with seawater and freshwater. (From Gupta, 2009). 
As described in greater detail by Gupta et al. (in prep), the maximum residence time of formation waters in the Alberta Basin is relatively long, approximately 210 million years. Thus the deepest fluids in this basin have indeed been preserved for hundreds of millions of years. This is contrary to predictions from previous hydrogeological models, and in agreement with geochemical interpretations. The residence time decreases significantly at shallower depths and is less than $100 \mathrm{Ma}$ in nearly all of the upper two km of the basin.

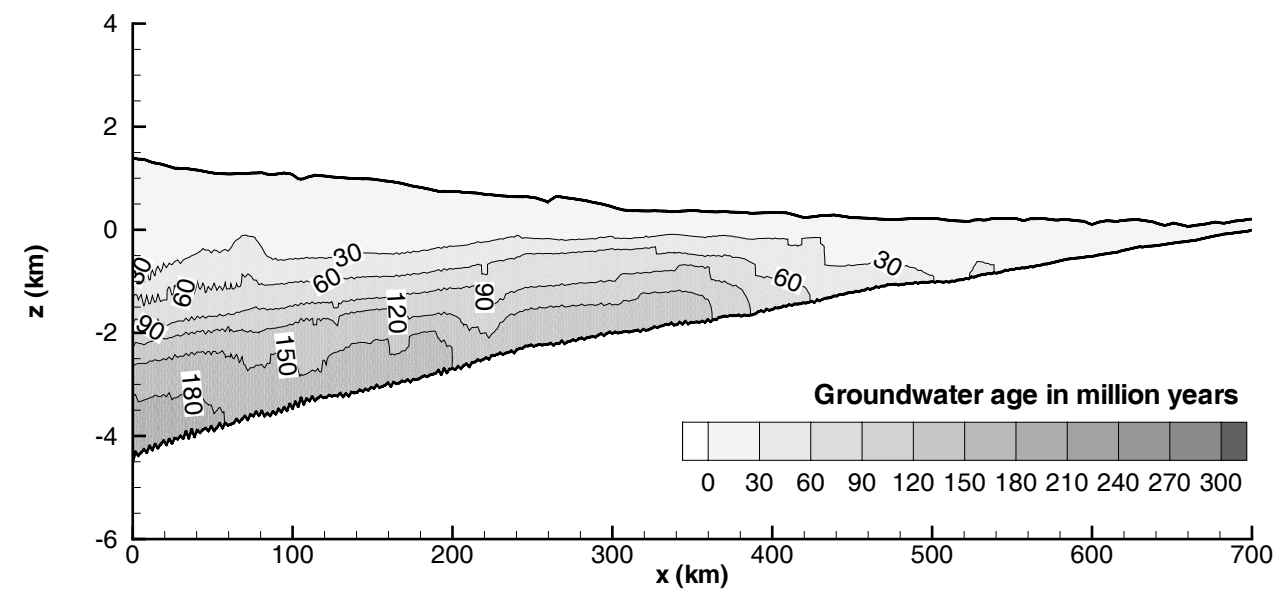

Figure 6. Residence time of pore fluids in the Alberta Basin. For a simulation in which the groundwater age at initial conditions is 300 My throughout the basin, it takes 129 My of simulation time (29 My into the future) to reach this distribution of ages. (From Gupta, 2009).

\section{Conclusion}

$\mathrm{Cl} / \mathrm{Br}$ compositions have been commonly used as indicators for interpreting the origin and evolution of sedimentary basin brines. Here we used hydrogeological models to arrive at a geologically reasonable explanation for the observed salinity and $\mathrm{Cl} / \mathrm{Br}$ ratios in the Alberta Basin. The resulting models, which are the first basin-scale models to be constrained in this way, indicate that brines in this basin reflect a four-end-member hydro-geochemical system that bears signatures of original residual brines formed by evaporation of seawater, halite dissolution, seawater and freshwater infiltration in various proportions and in different parts of the basin. Halite-bearing evaporite beds can act as a significant source of salinity in sedimentary basins. The presence of evaporites must be accounted for in numerical models of basin-scale transport.

Applying a combination of geochemical and hydrogeological constraints in this study also allowed us to constrain regional permeability values for the basin. The regional permeability values developed by Bekele (1999; 2002) explain oil migration, freshwater head and temperature distributions and, in this study, also explain the salinity and $\mathrm{Cl} / \mathrm{Br}$ ratios of the basin, provided that halite dissolution is included in the simulations. The distribution of salinity and $\mathrm{Cl} / \mathrm{Br}$ ratios could be reproduced without halite dissolution when extremely low permeabilities were used, but these permeabilities neither agree with field tests nor allow sufficient groundwater circulation to explain oil migration in the region. 
Mass transport is significant in the basin. Over the simulated $100 \mathrm{My}$, the maximum salinity in the deepest part of the basin had declined by $~ 55 \%$, due to a combination of diffusional losses and topography-driven flushing. The residence time of porefluids in the basin is nevertheless quite long in the deep western portion of the basin, reaching a maximum of $\sim 210 \mathrm{My}$. The residence time of porefluids in all but the shallowest parts of the basin are measured in tens of millions of years.

\section{References}

Adams, J.J., Rostron, B.J., and Mendoza, C.A., 2004, Coupled fluid flow, heat and mass transport, and erosion in the Alberta Basin: implications for the origin of the Athabasca Oil Sands: Canadian Journal of Earth Sciences, v. 41, p. 1077-1095.

Appold, M.S. and Garven, G., 1999, The hydrology of ore formation in the southeast Missouri District: Numerical models of topography-driven fluid flow during the Ouchita orogeny: Economic Geology, v.94, p. 913-936.

Bachu, S. and Burwash, R.A., 1994, Geothermal regime in the Western Canada Sedimentary Basin, in Mossop, G., and I. E. Shetsen, eds., Geological Atlas of the Western Canada Sedimentary Basin: Canadian Society of Petroleum Geologists and Alberta Research Council, p. 447-454.

Batzle, M., and Wang, Z., 1992, Seismic properties of pore fluids: Geophysics, v. 57, no.11, p. 1396-1408.

Bekele, E., 1999, Hydrogeologic controls on petroleum distribution within the Alberta Basin, Canada [Ph.D. Thesis]: University of Minnesota, 190 p.

Bekele, E., Person, M.A., Rostron, B, J., 2000, Anomalous pressure generation within the Alberta Basin: implications for oil charge to the Viking Formation: Journal of Geochemical Exploration, v. 69-70, p. 601-605.

Bekele, E. B., Person, M.A., Rostron, B.J., and Barnes, R., 2002, Modeling secondary oil migration with core-scale data: Viking Formation, Alberta Basin: American Association of Petroleum Geologists Bulletin, v. 86, no. 1, p. 55-74.

Billings, G.K., Hitchon, B., and Shaw, D.R., 1969. Geochemistry and origin of formation waters in the Western Canada Sedimentary Basin, 2. Alkali metals: Chemical geology, v. 4, p. 211-223.

Buschkuehle, B.E., Machel, H.G., 2002, Diagenesis and paleofluid flow in the Devonian Southesk-Cairn carbonate complex in Alberta, Canada, Marine and Petroleum Geology , p. 219-227

Bustin, R.M., 1991. Organic maturity in the Western Canada Sedimentary Basin: International Journal of Coal Geology, v. 19, p. 319-358.

Carpenter, A. B., 1978, Origin and chemical evolution of Brines in sedimenatry basins: Oklahoma Geological Survey Circular, v. 79, p. 60-77.

Chi, G., and Savard, M.M., 1997, Sources of basinal and Mississippi Valley-type mineralizing Brines: mixing of evaporated seawater and halite dissolution Br-ine, Chemical Geology, v.143, p. 121-125.

Connolly, C. A., Walter, L.M., Baadsgaard, H., and Longstaffe, F.J., 1990a, Origin and evolution of formation waters, Alberta Basin, Western Canada Sedimentary Basin. I. Chemistry: Applied Geochemistry, v. 5, p. 375-395.

Connolly, C. A., Walter, L.M., Baadsgaard, H., and Longstaffe, F.J., 1990b, Origin and evolution of formation waters, Alberta Basin, Western Canada Sedimentary Basin. II. Isotope systematics and water mixing: Applied Geochemistry, v. 5, p. 397-413.

Clayton, R.N., Friedman, I., Graf, D.L., Maveda, T.K., Meents, W.F., and Shimp, N.F., 1966, The origin of saline formation waters, I. Isotopic composition: Journal of Geophysical Research, v. 71, p. 38693882.

Demming, D., and Nunn, J., 1991, Numerical simulations of Br-ine migration by topographically driven recharge: Journal of Geophysical Research, v. 97(B2), p. 2485-2499.

Garven, G., 1985, The role of regional fluid flow in the genesis of the pine point deposit, Western Canada Sedimentary Basin: Economic Geology, v. 80, p. 307-324.

Garven, G., 1989, A hydrogeologic model for the formation of the giant oil sands deposits of the Western Canada Sedimentary Basin: American Journal of Science, v. 289, p. 105-166.

Ge, S., Garven, G., 1989, Tectonically Induced Transient Groundwater Flow in Foreland Basin; The Origin and Evolution of Sedimentary Basins and Their Energy and Mineral Resources, in Price, R.A., ed.,: American Geophysical Union, Washington, D.C. 
Grasby, S. E., and Chen, Z., 2005, Subglacial recharge into the Western Canada Sedimentary Basin impact of pleistocene glaciation on basin hydrodynamics: Geological Society of America Bulletin, v. 117, p. 500-514.

Gupta, I., 2009. Paleohydrogeology of the Alberta Basin, Canada. Dissertation, University of South Carolina, $221 \mathrm{p}$.

Hanor, J. S., 1994, Physical and chemical controls on the composition of waters in sedimentary basins: Marine and Petroleum Geology, v. 11, p. 31-45.

Hanor, J.S., and McIntosh, J.C., 2006, Are secular variations in seawater chemistry reflected in the compositions of basinal Brines?: Journal of Geochemical exploration, v. 89, p.153-156.

Hanor, J.S., and McIntosh, J.C., 2007, Diverse origins and timing of formation of basinal brines in the Gulf of Mexico sedimentary basin: Geofluids, v.7, p. 227-237.

Hitchon, B., and Friedman, I., 1969, Geochemistry and origin of formation waters in the Western Canada Sedimentary Basin - I. Stable isotopes of hydrogen and oxygen: Geochimica et Cosmochimica Acta, v. 33, p. 1321-1349.

Hitchon, B., Billings, G.K., and Klovan, J.E., 1971, Geochemistry and origin of formation waters in the Western Canada Sedimentrary Basin - III. Factors controlling chemical composition: Geochimica et Cosmochimica Acta, v. 35, p. 567-598.

Kharaka, Y.K., Maest, A.S., Carothers, W.W., Law, L.M., Lamothe, P.J., and Fries, T.L., 1987, Geochemistry of metal-rich Brines from central Mississippi Salt Dome basin, USA: Applied Geochemistry, v.2, p.543-561.

Machel, H. G., and P. A. Cavell, 1999, Low-flux, tectonically-induced squeegee fluid flow ("hot flash") into the Rocky Mountain Foreland Basin: Bulletin of Canadian Petroleum Geology, v. 47, p. 510533.

Majorowicz, J.A., Garven, G., Jessop, A., and Jessop, C., 1999, Present heat flow along a profile across the Western Canada Sedimentary Basin; the extent of hydrodynamic influence, in Forster, A., and Merriam, F.F., eds., Geothermics in Basin Analysis, Kluwer Academic/Plenum Publishers, New York., p. 61-79.

McIntosh, J.C., and Walter, L.M., 2005, Volumetrically significant recharge of Pleistocene glacial meltwaters into epicratonic basins: Constraints imposed by solute mass balances: Chemical Geology, v. 222, p. 292-309.

Michael, K., Machel, H.G., and Bachu, S., 2003, New insights into the origin and migration of Brines in deep Devonian aquifers, Alberta, Canada, Journal of Geochemical Exploration, v. 80, p.193-219.

Mossop, G., and Shetsen, I. E., 1994, Geological Atlas of the Western Canada Sedimentary Basin, Calgary: Canadian Society of Petroleum Geologists and Alberta Research Council, 510 p.

Nurkowski, J.R., 1984, Coal quality, coal rank variation and its relation to reconstructing overburden, Upper Cretaceous and Teritary Palins coals, Alberta, Canada: American Association of Petroleum Geologists Bulletin, v. 68, no. 3, p.285-295.

Spencer, R.J., 1987, Origin of Ca-Cl- Brines in Devonian formations, Western Canada Sedimentary Basin: Applied Geochemistry, v.2, p. 373-384.

Steuber, A.M. and Walter, L.M., 1991, Origin and chemical evolution of formation waters from SilurianDevonian strata in the Illinois Basin, USA: Geochimica et Cosmochimica Acta, v. 55, p. 309-325.

Walter, L.M. Steuber, A.M., and Huston, T.J., 1990, Br-Cl-Na systematics in Illinois basin fluids: constraints on fluid origin and evolution: Geology, v.18, p. 315-318.

White, D.E., 1965, Saline waters of sedimentary rocks, in Young, A., and Galley, J.E., eds., Fluids in Subsurface Environments: American Association of Petroleum Geologists Bulletin, mem. 4, p. 342-366.

Wilson, A.M., Garven, G., and Boles, J.R., 1999, Paleohydrogeology of the San Joaquin Basin, California: Geological Society of America Bulletin, v. 111(3), p. 432-449.

Wilson, A.M., 1999, Paleohydrogeology, mass transport and diagenesis in the San Joaquin Basin, California [PhD Thesis]: The Johns Hopkins University, 244 p.

Wilson, A.M., Fenstemaker, T., Sharp, J.M., Jr., 2003. Abnormally pressured beds as barriers to diffusive solute transport in sedimentary basins. Geofluids, 3(3): 203-212

Wright, G.N., ed. 1984, The Western Canada Sedimentary basin - A series of geological sections illustrating basin stratigraphy and structure. Calgary, Canadian Society of Petroleum Geologists \& Geological Association of Canada. 